\title{
ОДНОКОНТУРНЫЕ И ДВУХКОНТУРНЫЕ ТЕПЛОНАСОСНЫЕ СИСТЕМЫ. ВЗАИМОСВЯЗЬ ФИЗИЧЕСКИХ ПРОЦЕССОВ И ЭФФЕКТИВНОСТИ
}

\author{
С.В. Гошовский, докт. техн. наук, проф., А.В. Зурьян, канд. техн. наук \\ Украинский государственный геологоразведочный институт \\ 04114 ул. Автозаводская, 78А, Киев
}

\begin{abstract}
Приведен теоретический анализ особенностей использования и технологий построения теплонасосных систем в одноконтурном и двухконтурном исполнении. Выполнен анализ основных недостатков одноконтурных теплонасосных систем. Аналитически обосновано, что процесс теплообмена происходит при переменных температурах со стороны источника $и$ приемника теплоты, что ведет к дополнительным потерям в испарителе и конденсаторе и, соответственно, к снижению коэффициента трансформации теплонасосной системы. Экспериментально установлено, что уменьшение коэффициента трансформации происходит не прямо пропорционально увеличению температуры подаюшего теплоносителя, а имеет некоторое ускорение, обусловленное повышением тепловых потерь в системе, связанных с увеличением давления и температуры. Представлен действующий макет разработанной и сконструированной в УкрГГРИ двухконтурной экспериментальной теплонасосной установки. Описана методика проведения исследований. Приведены характеристики измерительного оборудования, установленного на макете экспериментальной установки и программного обеспечения, которое использовалось для архивирования и визуализации данных, полученных в прочессе проведения исследований. Изложены результаты научной работы, полученные в ходе теоретических расчетов и экспериментальных исследований эффективности теплонасосных систем, в зависимости от одноконтурного или двухконтурного исполнения. Даются зависимости коэффициента трансформации теплового насоса от количества контуров. Обоснованы зависимости эффективности теплонасосной системы от параметров первичного источника низкопотенциального тепла и конструктивных особенностей системы теплоснабжения. Сделан вывод, что двухконтурная система с последовательно соединенными контурами работает эффективнее, чем одноконтурная. Библ. 38, табл.1, рис. 6.
\end{abstract}

Ключевые слова: тепловой насос, двухконтурный тепловой насос, энергия окружающей среды, возобновляемые источники энергии.

\section{SINGLE-CIRCUIT AND DUAL-CIRCUIT HEAT PUMP SYSTEMS. INTERRELATION OF PHYSICAL PROCESSES AND EFFICIENCY}

\author{
S. Goshovskyi, doctor of technical science, professor, O. Zurian, candidate of technical science \\ Ukrainian State Geological Research Institute
} 04114, 78A Avtozavodska St., Kyiv, Ukraine

It contains the theoretical analysis of special aspects of the use and technologies used for single and dual circuit heat pump systems. The analysis of major disadvantages of single circuit heat pump systems is conducted. It is analytically proved that heat exchange process occurs at variable temperatures of the heat source and heat sink and it causes stray load loss in an evaporator and condenser and, correspondently, it decreases the coefficient of performance of the heat pump system. Experiments proved that decrease of the coefficient of performance is not positively associated with increase of the temperature of supply heat transfer medium, but it has some acceleration caused by increase of the system heat loss related to increase of pressure and temperature. It demonstrates functioning model of the experimental dual circuit heat pump system developed and designed by UKRSGRI. It describes the research procedure. It contains specifications of measuring equipment used for the experimental system model and of software used for archiving and visualization of data obtained during research conduction. It states the results of scientific work received by theoretical calculations and experimental testing of the heat pump system efficiency depending on one or dual circuit version. The dependence of heat pump coefficient of performance on the number of circuits is shown. It explains the dependence of the heat pump system efficiency on characteristics of the primary source of low-grade heat and design features of the heat supply system. The conclusion is drawn that the dual circuit system with circuits connected in series is more efficient than the single circuit one. Ref. 8, tab. 8, fig. 4 . Keywords: heat pump, dual-circuit heat pump, energy of environment, renewable energy sources. 

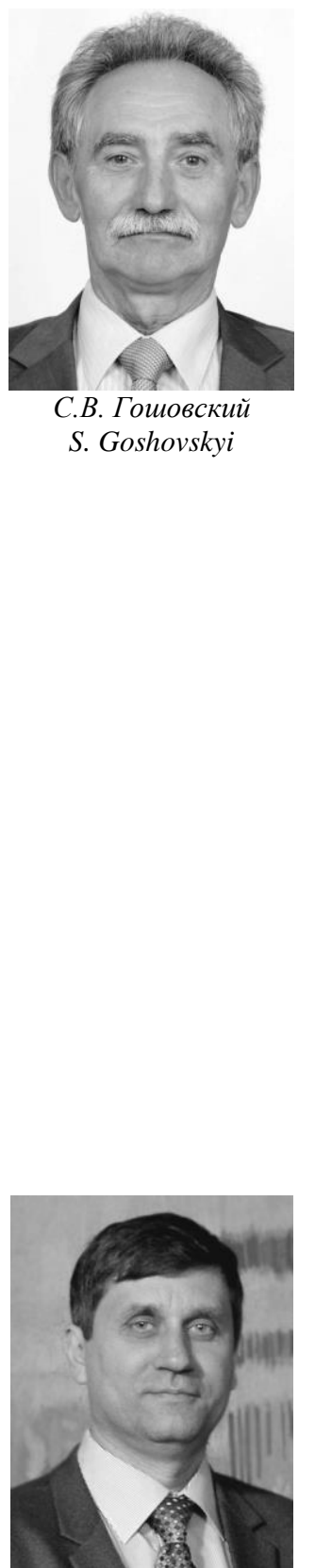

A.B. Зурьян

O. Zurian
Сведения об авторе: директор Украинского государственного геологоразведочного института, профессор, доктор технических наук. Произведенные автором фундаментальные исследования по приминению геофизических методов изучения горных пород и использование энергии взрыва в технологиях бурения скважин при поисках и разведке нефти и газа, заложили научную базу принципиально нового для украинской науки направления изучения геологической среды и конструирования прострелочно-взрывных приборов, которые используются в глубоких скважинах. При его участии разведано ряд нефтегазовых месторождений, которые имеют народнохозяйственное значение для Украины.

Образование: Киевский национальный университет им. Т. Шевченко. Специальность: геолог-геофизик.

Научная сфера: исследования минерально-сырьевой базы Украины, методика геологических и геофизических исследований, технология интенсификации добычи нефти и газа, бурение скважин, технология с использованием энергии взрыва, приборостроение.

Публикации: более 350, в т.ч. 19 монографий, 154 авторских изобретений и патентов.

ORCID: 0000-0002-8312-6244

Контакты: +38 (044) 430-70-24

e-mail: ukrdgri@ukrdgri.gov.ua

Сведения об авторе: заведующий отделом инновационных технологий Украинского государственного геологоразведочного института, кандидат технических наук.

Образование: Ставропольское высшее военное инженерное училище связи (1987). Специальность: инженер радиосвязи. Киевский национальный университет им. Т. Шевченко (2012). Харьковский национальный университет

им. В. Каразина (2016) - защита диссертации по теме «Экологически безопасные возобновляемые источники получения тепловой энергии».

Научная сфера: возобновляемая энергетика, проэктирование энергоэфективных зданий, проектирование систем, которые работают за счет возобновляемых источников энергии; добыча (разработка) нетрадиционных источников углеводородов, устойчивое развитие и экологическая безопасность; технологии получения тепловой энергии для систем отопления с использованием теплонасосных систем и тепла атмосферного воздуха, солнечная энергия и низкотемпературная энергия приповерхностных слоев Земли.

Публикации: более 50, 16 авторских патентов на изобретение и полезную модель.

ORCID: 0000-0002-2391-1611

Контакты: +38 (050) 778-30-29

e-mail: alexey_zuryan@ukr.net
Information about the author: director of the Ukrainian State Geological Research Institute, professor, doctor of technical sciences. Sergii Goshovskyi's fundamental research on the application of geophysical methods on application of geophysical methods to study rocks and explosion energy in wells construction technology for search and exploration of oil and gas, has laid the fundamentally new scientific basis for Ukrainian science to study of the geological environment and explosive device design used in the deep wells.

With his participation explored several oil and gas deposits, which have economic importance for Ukraine.

Education: Taras Shevchenko National University of Kyiv. Specialty: geologist - geophysicist

Research area: mineral resource base of Ukraine research, methods of geological and geophysical research, a technology of oil and gas production intensification, drilling technology, technology of the explosion energy using, engineering.

Publications: over 350 scientific publications, including 19 monographs, and 154 inventions and patents.

ORCID: 0000-0002-8312-6244

Contacts: +38 (044) 430-70-24

e-mail: ukrdgri@ukrdgri.gov.ua

Information about the author: head of the Department of Innovative Technologies of the Ukrainian State Geological Research Institute, candidate of technical sciences. Education: Stavropol higher military engineering academy of communication. Specialty: engineer of radiocommunication. Oleksii Zurian has a higher engineering and humanitarian education. In 1987, graduated from the Stavropol higher military engineering academy of communication, and in 2012, Taras Shevchenko National University of Kyiv. In 2016 at the V.N. Karazin Kharkiv National University defended his dissertation on the theme «Environmentally safe renewable sources of thermal energy»).

Research area: renewable energy, designing energy efficient buildings, designing systems that operate at the expense of renewable energy sources; extraction (development) of non-traditional sources of hydrocarbons, renewable energy sources, sustainable development and ecological safety; technologies for obtaining thermal energy for heating systems using heat pump systems and heat of atmospheric air, solar energy and lowtemperature energy of near-surface layers of the Earth.

Publications: over 50 scientific publications, and 16 patents for invention and utility model.

ORCID: 0000-0002-2391-1611

Contacts: +38 (050) 778-30-29

e-mail: alexey_zuryan@ukr.net 
Список использованных обозначений и сокращений: НПИТ - низкопотенциальный источник тепла;

УкрГГРИ - Украинский государственный геологоразведочный институт;

$P A$ - рабочий агент;

$P T$ - рабочее тело;

Постановка проблемы. Мировая экономика в начале третьего тысячелетия характеризуется существенным противоречием между постоянным увеличением потребления энергоресурсов в процессе производства и обострением экономических проблем, связанных с ростом расходов на ее потребление. Это приводит к необходимости как поиска новых экономически выгодных и экологически безопасных источников энергии, так и к разработке и производству эффективных устройств ее преобразования в энергию, удобную для потребления.

Использование альтернативных экологически чистых источников энергии может, если не предотвратить энергетический кризис в Украине, то значительно его смягчить. Вследствие этого, наряду с поисками и освоением традиционных источников (газ, нефть), перспективным направлением является использование возобновляемой энергии, накапливаемой в водоемах, грунте, геотермальных источниках, технологических выбросах (воздух, вода, стоки и др.). Однако температура этих источников довольно низкая $\left(0-25^{\circ} \mathrm{C}\right)$ и для эффективного их использования необходимо осуществить перенос этой энергии на более высокий температурный уровень (50 $\left.100^{\circ} \mathrm{C}\right)$. Реализовать такое преобразование возможно с помощью тепловых насосов [23].

Анализ последних исследований и публикаций. В условиях растущего энергетического кризиса ведутся значительные научные исследования, направленные на поиск вариантов замещения в системах энергоснабжения доли энергии из возобновляемых источников $[14,15,17,29]$. Одним из направлений обеспечения энергетического баланса энергоснабжения является использование низкопотенциальной энергии Земли, воды, воздуха и др. с помощью теплонасосных систем $[2,3,6,7]$. Преобразование низкопотенциальной энергии в тепловую обеспечивает существенную экономию традиционных энергоресурсов, минимизирует сжигания углеводородов и уменьшает выбросы загрязняющих веществ в окружающую среду $[1,10,13,16,18,19]$. Причем тепловая энергия, полученная с помощью тепловых насосов и может быть использована непосредственно в системах отопления, горячего водоснабжения и для технологических нужд [21, $20,24,38]$. В летний период теплонасосные системы могут обеспечить потребности в технологическом холоде [22, 28].
СОР - коэффициент трансформации;

$T H$ - тепловой насос;

ТНУ - теплонасосная установка;

ТСП - термопреобразователь сопротивления.

Базовые типы тепловых насосов методом парных сравнений согласно методике [32] исследованы в работах $[12,34]$. Анализ эффективности различных типов тепловых насосов приведено в работе [27]. В исследовании [25] предложен новый подход к оценке эффективности тепловых насосов. Авторами [26] выполнен анализ ТН как с электрическим, так и когенерационным приводом. В работе [8] проведена оценка эффективности разных вариантов тепловых насосов по коэффициенту использования первичной энергии. Авторами [5, 11] выполнен термодинамический анализ разных типов $\mathrm{TH}$.

Постановка задачи. Цель нашего исследования - обоснование эффективности использования в системах теплоснабжения, кондиционирования и холодоснабжения производственных, административных, складских помещений двухконтурных тепловых насосов.

Сегодня с уверенностью можно сказать, что первые шаги на этом пути уже сделаны. Но они еще достаточно медленные. Вопрос, какие же тепловые насосы наиболее целесообразны для дальнейшей разработки и внедрения, до сих пор недостаточно обоснованы. Отсутствует научная техническая база для изготовления двухконтурных теплонасосных систем. Актуальными остаются вопросы разработки методик проектирования кластерных ТН. Нет сравнительного анализа эффективности работы одноконтурных, многоконтурных и кластерных теплонасосных систем. Вместе с тем надо отметить, что соединение однотипных устройств в различных сферах техники с целью повышения эффекта от их сложения известно давно и широко применяется.

Изложение основного материала. Теплонасосная установка (ТНУ) состоит из теплообменника-испарителя, компрессора, теплообменникаконденсатора и дросселя. В качестве рабочего тела (РТ) установки применяются рабочие агенты (PA): фреоны, аммиак, пропан и др. [34].

Основным показателем эффективности теплового насоса является коэффициент трансформации (тепловой коэффициент) $\varphi$ :

$$
\varphi=Q_{1} / N=\left(Q_{2}+N\right) / N=T_{2} /\left(T_{2}-T_{11}\right),
$$

где $Q_{1}$ - теплопроизводительность ТНУ, Вт; $\mathrm{N}$ - мощность компрессора, Вт; $T_{2}$ - температура теплоносителя на выходе из конденсатора, К; $T_{11}$ - температура теплоносителя на входе в испаритель, К. 
Теоретические значения коэффициента трансформации могут достигать величин 7-8. Реальные значения при работе в оптимальном режиме, что экспериментально установлено авторами составляют, величины 3-4. Это означает, что на 1 кВТ мощности электрической энергии можно получить 3-4 кВт мощности тепловой энергии.

Существенным недостатком теплового насоса является необходимость подвода и отвода теплоты при постоянной температуре, что практически невозможно [37]. В действительности процесс теплообмена происходит при переменных температурах со стороны источника и приемника теплоты, что ведет к дополнительным потерям в испарителе и конденсаторе и, соответственно, к снижению коэффициента трансформации.
Действительный коэффициент трансформации теплового насоса $\varphi$ должен иметь вид:

$$
\varphi=\varphi_{T} \eta_{T H}
$$

где $-\eta_{\text {тн }}$ коэффициент потерь, учитывающий реальные процессы, которые осуществляются рабочим телом в ТН, который можно принять 0,5 [8].

Из соотношения (1) и (2) можем определить действительный коэффициент трансформации теплового насоса $\varphi$ в системе с контуром теплых полов с температурой подающей линии $45{ }^{\circ} \mathrm{C}$ и контуром отопления с радиаторами и температурой $60{ }^{\circ} \mathrm{C}$ при условии, что температура первичного источника тепла равна $5{ }^{\circ} \mathrm{C}$.

Результаты расчета коэффициента трансформации теплового насоса $\varphi$ в зависимости от температуры подающей линии $T_{2}$ сведены в таблицу 1 .

Таблица 1. Зависимость коэффициента трансформации теплового насоса $\varphi$ от температуры подающей линии Т 2

Table 1. Dependence of the transformation coefficient of the heat pump $\varphi$ on the temperature at the heat supply line $T_{2}$

\begin{tabular}{|c|c|c|c|c|c|c|c|c|c|c|c|c|}
\hline $\mathrm{T}_{2},{ }^{\circ} \mathrm{C}$ & 30,00 & 35,00 & 40,00 & 45,00 & 50,00 & 55,00 & 60,00 & 65,00 & 70,00 & 75,00 & 80,00 & 85,00 \\
\hline$\varphi$ & 6,06 & 5,13 & 4,47 & 3,98 & 3,59 & 3,28 & 3,03 & 2,82 & 2,64 & 2,49 & 2,35 & 2,24 \\
\hline
\end{tabular}

Анализ полученных данных свидетельствует, что коэффициент трансформации существенно зависит от температуры подающей линии.

В ходе проводимых в Украинском Государственном геологоразведочном институте исследований на экспериментальной геотермальной установке было установлено, что уменьшение коэффициента трансформации $\varphi$ происходит не прямо пропорционально увеличению температуры подающего теплоносителя, а имеет некоторое ускорение, обусловленное повышением тепловых потерь в системе связанное с увеличением давления и температуры (рис. 1). При этом коэффициент ускорения - $\eta_{y}$ увеличивается пропорционально увеличению температуры подающего теплоносителя. Вследствие предложенной гипотезы действительный коэффициент трансформации теплового насоса $\varphi$ принимает вид:

$$
\varphi=\varphi_{T} \cdot \frac{\eta_{T H}}{\eta_{y}}=\frac{T_{2}}{T_{2}-T_{11}} \cdot \frac{\eta_{T H}}{\eta_{y}} .
$$

При этом надо отметить, что наибольшая эффективность насоса достигается при температуре подающего теплоносителя $35-45^{\circ} \mathrm{C}$, что обуславливает определенные технические требования к системе теплообеспечения и утепления здания.

Основным недостатком теплового насоса является обратная зависимость его эффективности от разницы температур между источником теплоты и потребителем. Это накладывает определённые ограничения на использование систем типа «воздух - вода» или «воздух - воздух». При минусовой температуре первичного источника теплоты тепловой насос не только резко снижает температуру подающей линии, но у него также падает мощность.

На графике (рис. 2) приведена зависимость коэффициента трансформации $\varphi$ от температуры конденсации $t_{c d}$ для воздушного теплового насоca, в котором в качестве холодильного агента был применен фреон R 134a. Расчет выполнен с применением математического аппарата [30] для температуры конденсации $t_{e v}-5$ и $-20^{\circ} \mathrm{C}$ coответственно. 


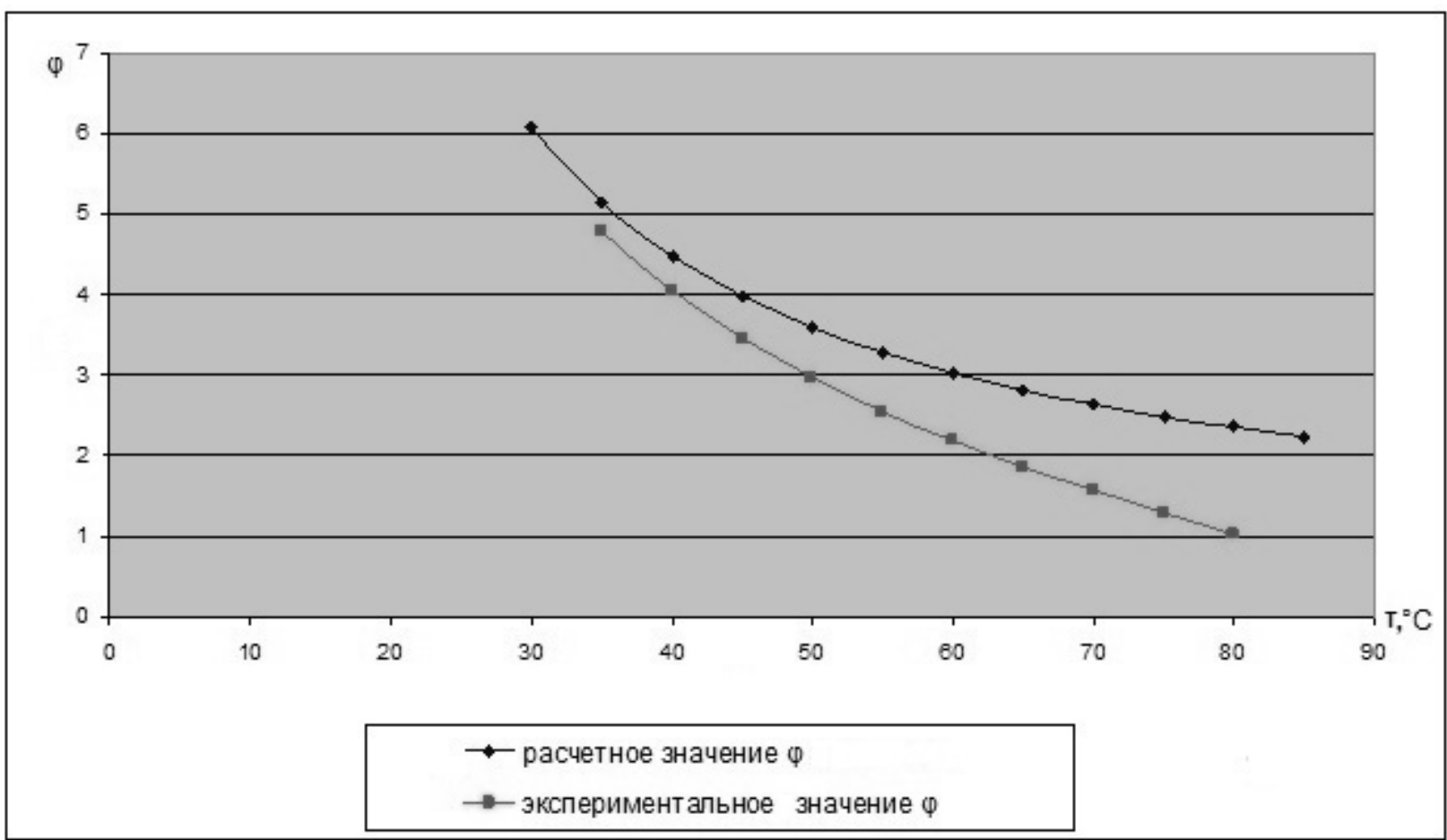

Рис. 1. Зависимости коэффициента трансформации теплового насоса ф от температуры подающей линии.

Fig. 1. Dependence of the transformation coefficient of the heat pump $\varphi$ on the temperature at the heat supply line.

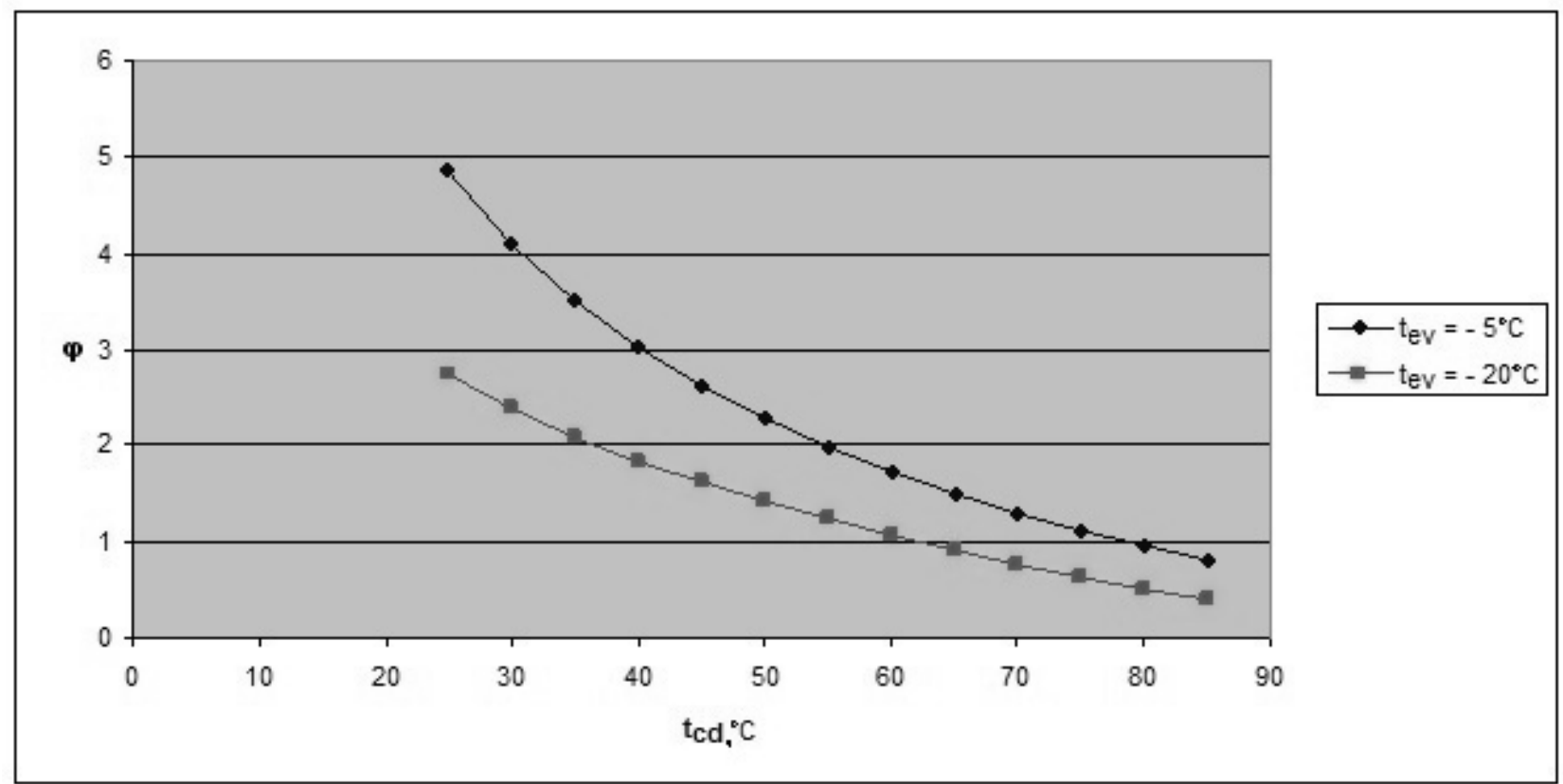

Рис. 2. Зависимость коэффициента трансформации $\varphi$ от температуры конденсации $t_{c d}$ для теплового насоса (температура кипения $-t_{e v}=5^{\circ} \mathrm{C}$ и $-20^{\circ} \mathrm{C}$, фреон $\left.\mathrm{R} 134 \mathrm{a}\right)$.

Fig. 2. Dependence of the transformation coefficient $\varphi$ on the condensation temperature tcd for the heat pump (boiling point $t_{e v}=5^{\circ} \mathrm{C}$ and $-20{ }^{\circ} \mathrm{C}$, Freon $\mathrm{R}$ 134a).

Из проведенных аналитических исследований можно сделать вывод, что реальные значения эффективности современных тепловых насосов COP (Coefficient of Perfomance) составляют порядка $\mathrm{COP}=2.0$ при температуре источника $-20^{\circ} \mathrm{C}$, и порядка $\mathrm{COP}=4.0$ при температуре источника $+5{ }^{\circ} \mathrm{C}$. Это приводит к тому, что для обеспечения заданного температурного режима потребителя при низких температурах воздуха необходимо использовать оборудование со значительной избыточной мощностью, что сопряжено с нерациональным использованием капиталовложений.

Одним из путей повышения эффективности теплонасосной системы является уменьшение 
корреляции зависимости температуры рабочего агента в испарителе и конденсаторе от выходной температуры НПИТ потребителя может быть использование - цикла Лоренса.

Применение идеального цикла Лоренса на практике невозможно. Приближение к нему возможно в частности путем соединения нескольких компрессионных ТНУ в одну систему.

С целью исследований эффективности работы двухконтурного теплового насоса в Украинском государственном геологоразведочном институте (УкрГГРИ) была сконструирована двухконтурная экспериментальная теплонасосная система (рис. 3).

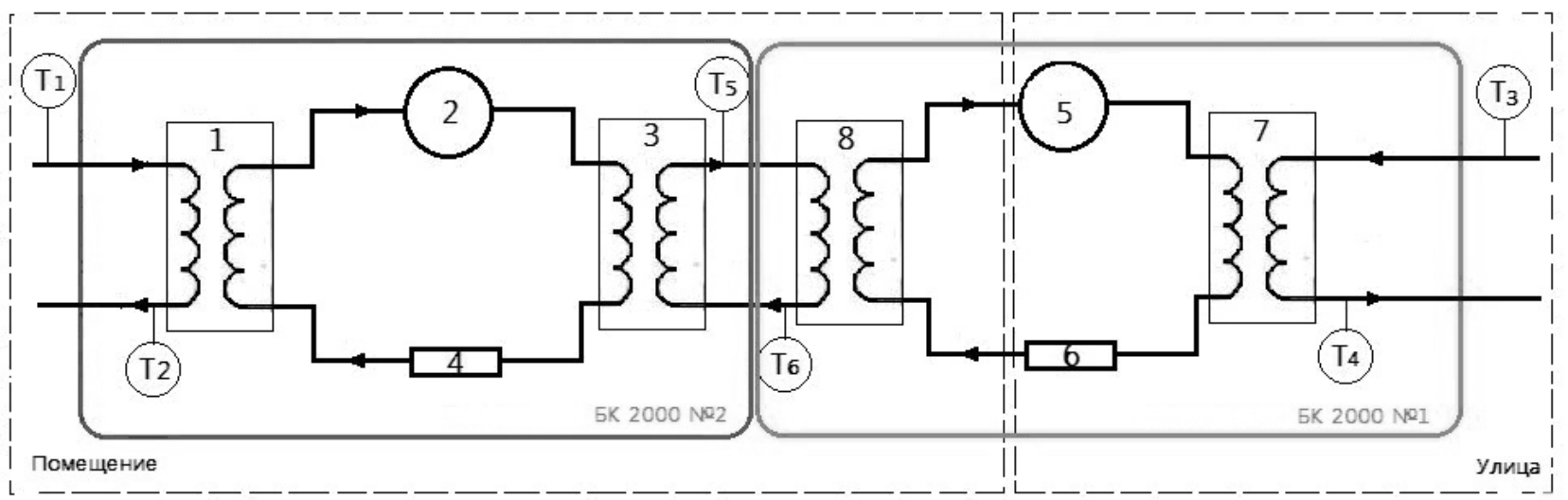

Рис. 3. Схема экспериментальной установки с местами установки датчиков температуры: $T_{1}-$ датчик температуры 6 помещении; $T_{2}$ - датчик температуры воздуха на выходе из испарителя второго кондиционера; Тз - датчик температуры воздуха на улице; $T_{4}$ - датчик температуры воздуха на выходе из конденсатора первого кондиционера; $T_{5}$ - датчик температуры воздуха на выходе из конденсатора второго кондиционера; $T_{6}$ - датчик температуры воздуха на выходе из испарителя первого кондиционера; 1-испаритель второго кондиционера; 2 - компрессор второго кондицонера; 3 - конденсатор второго кондицонера; 4 - терморегулирующий вентиль второго кондиционера; 5 - компрессор первого кондиционера; 6 - терморегулирующий вентиль первого кондиционера; 7 - конденсатор первого кондиционера;

8 -испаритель первого кондиционера.

Fig. 3. Diagram of the experimental installation with the locations of the temperature sensors: $T 1$ - the temperature sensor in the room; T2 - air temperature sensor at the outlet of the evaporator of the second air conditioner; T3 - outdoor temperature sensor; T4 - air temperature sensor at the output of the condenser of the first air conditioner; T5 - air temperature sensor at the outlet of the condenser of the second air conditioner; T6 - air temperature sensor at the output of the evaporator of the first air conditioner; 1 -evaporator of the second air conditioner; 2 - compressor of the second air conditioner; 3 - the condenser of the second conditioner; 4 - thermostatic valve of the second air conditioner; 5 - compressor of the first air conditioner; 6 - thermostatic valve of the first air conditioner; 7 -condenser of the first air conditioner; 8 -evaporator of the first air conditioner.

Двухконтурная экспериментальная теплонасосная система УкрГГРИ состоит из испарителя первого контура 8 , компрессора первого контура 5 , компрессора второго контура 2, конденсатора второго контура 3 и испарителя второго контура 1, конденсатора первого контура 7, дросселя первого контура 6 и дросселя второго контура 4 . К испарителю 1 подводится теплоноситель с низкой температурой. В испарителе он отдает тепловую энергию жидкому хладагенту для его испарения и повышения энтальпии. В компрессоре 2 пары хладагента сжимаются, что сопровождается повышением температуры, и нагнетаются в конденсатор второго контура 3, совмещенного с испарителем первого контура теплового насоса 8.

Предполагается, что данная схема подключения тепловых насосов позволяет получить увеличение температуры подачи теплоносителя в систему кондиционирования здания при миними- зации затрат внешней энергии.

Для измерений температуры использовались температурные датчики (термопреобразователи сопротивления) ТСП-204 (рис. 4.1). Рабочий диапазон измеряемых температур от -40 до $+270{ }^{\circ} \mathrm{C}$. Показатель тепловой инерции не более 6-8 сек. Для приема и преобразования сигналов, поступающих от термопреобразователей сопротивления, в значения температуры, и отображения их на встроенном цифровом индикаторе применялся измеритель восьмиканальный с блоком расширения аналоговых входов И8 8TC/10-RS485-БП-12ИПК-Щ (рис. 4.2). С целью визуализации в режиме реального времени данных, полученных с датчиков, записи их в архив, отображение полученных данных в виде таблиц или графиков, использовался индикатор логгер И16П RS 485/43-USBGSM-ИПR-Д (рис. 4.2) и программное обеспечение (система сбора данных) РегМик (рис. 4.4). 


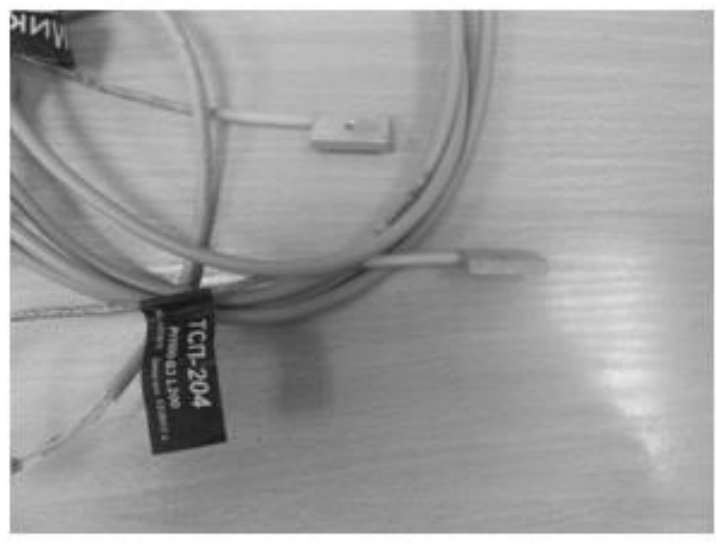

1

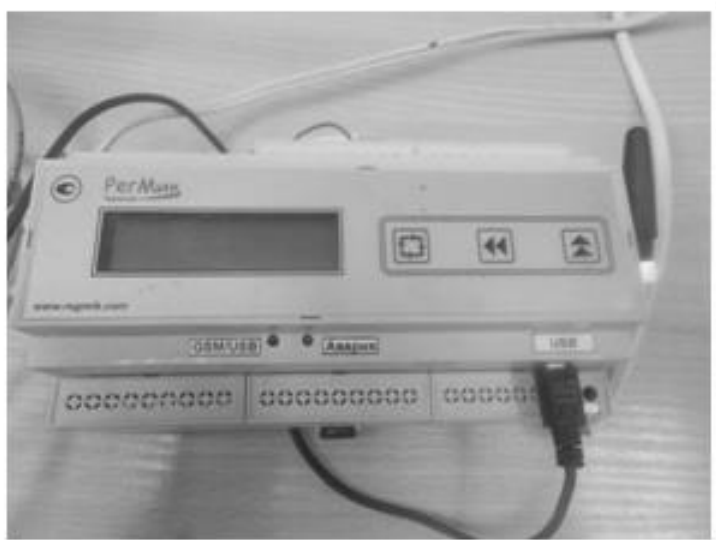

3

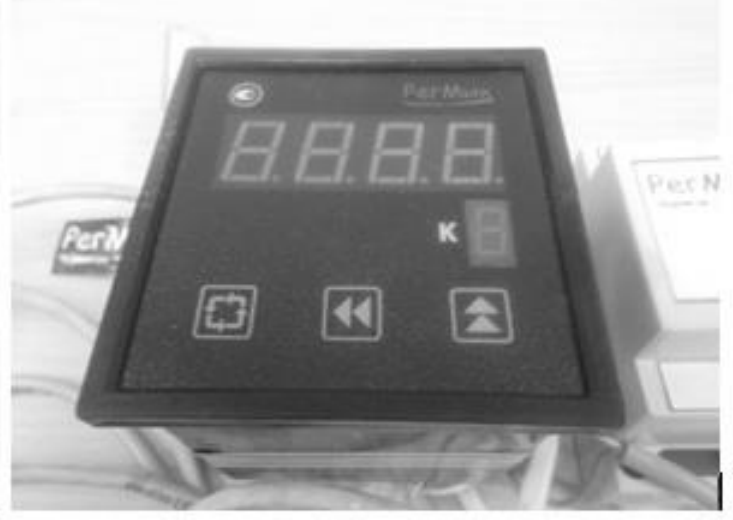

2

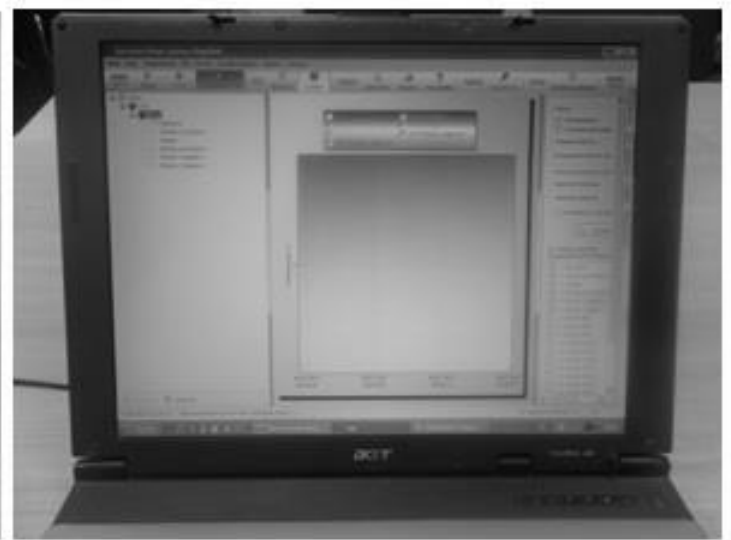

4

Рис. 4. Основное измерительное оборудование, которое использовалось для проведения эксперимента: $1-$ температурные датчики (термопреобразователи сопротивления) ТСП-204; 2 - измеритель восьмиканальный с блоком расширения аналоговых входов И8 8TC/10-RS485-БП-12-ИПК-Щ; 3 - индикатор логгер И16П RS 485/43-USB-GSM-ИПR-Д; 4 - программное обеспечение (система сбора данных) РегМик.

Fig. 4. The main measuring equipment used for the experiment: 1 -temperature sensors (thermal resistance transducers) ТСП-204; 2 - an eight-channel meter with an extension block of analog inputs И8 8TS/10-RS485-БП-12-ИПК-Щ; 3 - the indicator logger И16П RS 485/43-USB-GSM-IPR-D; 4 - software (data collection system) RegMik.

Измерения проводились в трех режимах работы модуля с последовательно соединенными кондиционерами. В первом режиме оба кондиционера работали с одинаковыми режимами производительности (режим 11), а в двух последующих режимах уменьшалась производительность одного модуля (кондиционера) по отношению к другому (режим 10 и 01). Переключение режимов производилось тумблером «Макс/Мин» на панели управления кондиционеров.

В процессе исследования были произведены измерения температур и рассчитаны такие параметры холодильных машин как коэффициент трансформации, полезная мощность и затраты внешней энергии для работы системы. Выполнен сравнительный анализ эффективности кондиционеров работающих в паре (последовательном соединении) и одиночного кондиционера.

Экспериментально было установлено, что температуры $\mathrm{T}_{2}, \mathrm{~T}_{4}, \mathrm{~T}_{5}, \mathrm{~T}_{6}$ коррелируются с тем- пературой $\mathrm{T}_{3}$ (температура на улице), а температура $\mathrm{T}_{1}$ (температура в помещении) фактически поддерживается неизменной. Кондиционер, подключенный вторым, работает стабильно. Девиация температур $\mathrm{T}_{2}$ и $\mathrm{T}_{5}$ незначительная. $\mathrm{B}$ то же время кондиционер, подключенный первым, работает прерывисто. Девиация температур $\mathrm{T}_{4}$ и $\mathrm{T}_{6}$ значительная.

Выполнен анализ производительности системы в зависимости изменения производительности каждого из подключенных к системе моноблочных кондиционеров. Также выполнен сравнительный анализ эффективности роботы системы, состоящей из двух последовательно подключенных моноблочных кондиционеров и системы, состоящей из одного моноблочного кондиционера.

Графики изменения температур в контрольных точках двухконтурной и одноконтурной холодильной систем изображены на рис. 5 и рис. 6 соответственно. 


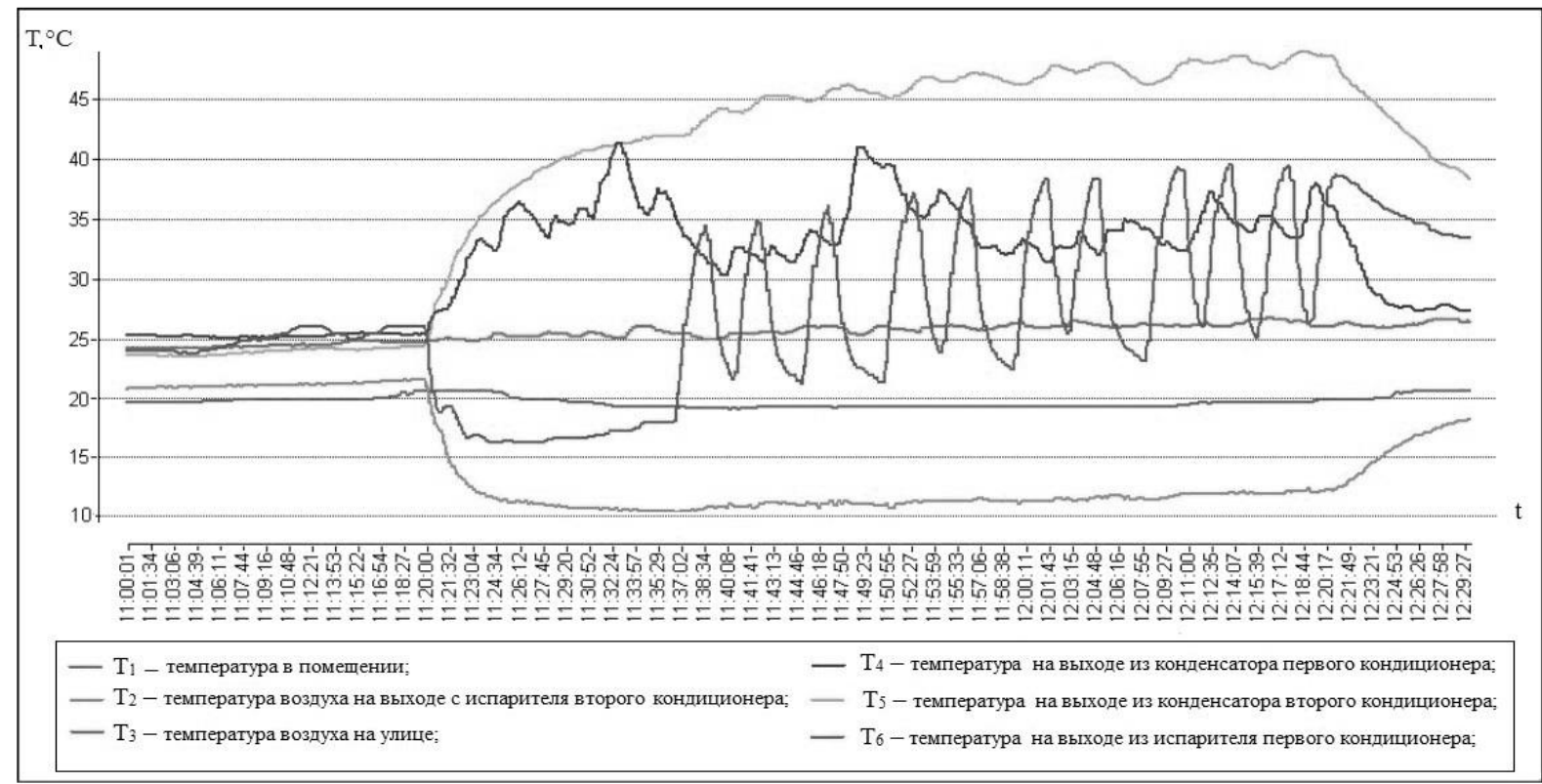

Рис. 5. График изменения температур в контрольных точках двухконтурной холодильной системы (последовательно соединенных двух моноблочных кондиционеров).

Fig. 5. Graph of temperature changes in the control points of a two-circuit refrigeration system (in series connected two monoblock conditioners).

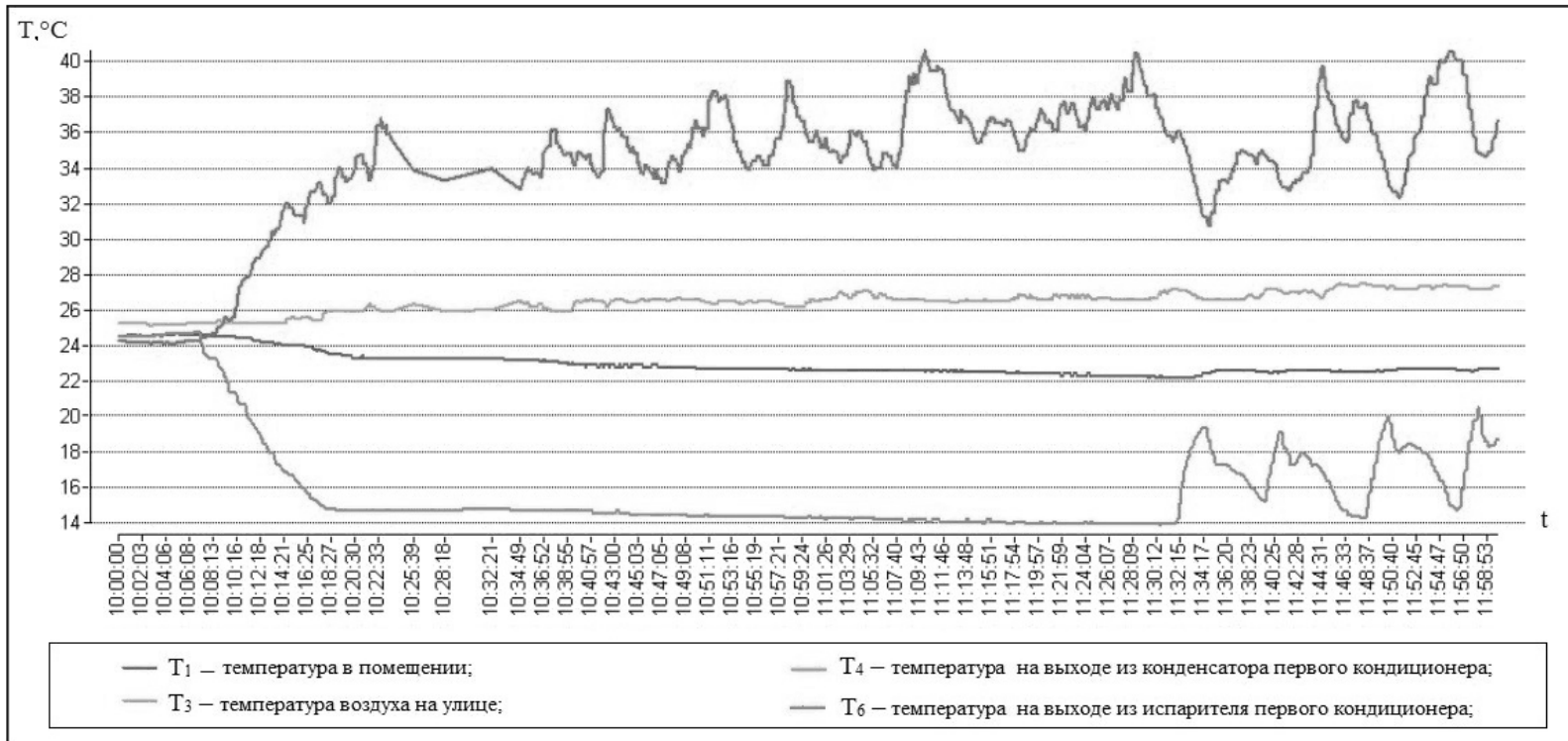

Рис. 6. График изменения температур в контрольных точках одноконтурной холодильной системы (после демонтажа второго кондиционера).

Fig. 6. Graph of temperature changes in the control points of a single-circuit refrigeration system (after dismantling the second air conditioner).

Экспериментально установлено, что уменьшение производительности одного из моноблоков влечет к уменьшению производительности системы в целом.

Известно, что основными параметрами холодильных машин являются:

1. Коэффициент полезного действия или коэффициент термической (термодинамической) эффективности. Этот коэффициент представляет со- бой отношение холодильной мощности и электрической мощности, потребляемой компрессором.

2. Коэффициент трансформации (холодильный коэффициент) - величина, характеризующая энергетическую эффективность работы холодильной машины (равна отношению холодопроизводительности к количеству энергии (работе)), затраченной за единицу времени на осуществление холодильного цикла. Он зависит от темпера- 
турных условий её работы, и определяется выражением $\varepsilon_{\mathrm{K}}=\mathrm{T}_{0} /\left(\mathrm{T}-\mathrm{T}_{0}\right)$, где $\mathrm{T}_{0}$ и $\mathrm{T}-$ абсолютные температуры охлаждаемого объекта и окружающей среды (кипения и конденсации хладагента).

Соотношение коэффициента полезного действия двухконтурной системы к одноконтурной будет иметь вид:

$$
K_{21}=\frac{\eta_{2}}{\eta_{1}}
$$

где $\eta_{2}$ - коэффициент полезного действия двухконтурной системы, $\eta_{1}-$ коэффициент полезного действия одноконтурной системы.

Учитывая, что

$$
\eta_{2}=\frac{P_{x 2}}{P_{э 2}}, \text { a } \eta_{1}=\frac{P_{x 1}}{P_{э 1}},
$$

где $P_{x 1}$ и $P_{x 2}-$ холодильная мощность одноконтурной и двухконтурной системы соответственно, $P_{э 1} P_{э 2}$ - электрическая мощность, потребляемая компрессором одноконтурной и двухконтурной системы соответственно.

С учетом (5) выражение (4) примет вид:

$$
K_{21}=\frac{P_{x 2}}{P_{э 2}} \cdot \frac{P_{\ni 1}}{P_{x 1}}=\frac{P_{x 2}}{P_{x 1}} \cdot \frac{P_{\ni 1}}{P_{э 2}},
$$

Для определения номинального значения $K_{21}$ найдем номинальные значения соотношения холодильных мощностей двухконтурной и одноконтурной системы $-K_{p x 21}$ и номинальные значения отношения электрических мощностей потребляемых компрессором одноконтурной и двухконтурной систем $-K_{\epsilon 12}$

$$
\begin{aligned}
K_{p x 21}=\frac{P_{x 2}}{P_{x 1}}= & \frac{V \cdot c \cdot\left(T_{\max p x 2}-T_{\min p x 2}\right)}{V \cdot c \cdot\left(T_{\max p x 1}-T_{\min p x 1}\right)}= \\
& =\frac{\Delta T_{\max p x 2}}{\Delta T_{\max p x 1}},
\end{aligned}
$$

где $V$ - объем охлаждаемого помещения; $c$ удельная теплоемкость воздуха, $T_{\max p x 2}$ и $T_{\min p x 2}-$ максимальная и минимальная температура воздуха в помещении за единицу времени работы двухконтурной системы, $T_{\max p x 1}$ и $T_{\min p x 1}$ - максимальная и минимальная температура воздуха в помещении за единицу времени работы одноконтурной системы, $\Delta T_{\max p x 2}$ и $\Delta T_{\max p x 1}-$ разница между максимальной и мини- мальной температурой воздуха в помещении за единицу времени работы двухконтурной и одноконтурной систем соответственно.

Подставив в формулу (5) значения температур, полученных в ходе исследования, получаем значение $K_{p x 21}=2,17$.

Принимая во внимание, что во время проведения эксперимента компрессоры обоих кондиционеров работали совместно в двухконтурной системе, в то время когда в одноконтурной системе работал только один компрессор, параметр $K_{\epsilon 12}$ будет иметь следующее значение:

$$
K_{\epsilon 12}=\frac{P_{э 1}}{P_{э 2}}=\frac{1}{2}=0,5 .
$$

Исходя из этого, можно рассчитать значение $K_{21}$

$$
\begin{gathered}
K_{21}=\frac{P_{x 2}}{P_{\ni 2}} \cdot \frac{P_{\ni 1}}{P_{x 1}}=\frac{P_{x 2}}{P_{x 1}} \cdot \frac{P_{\ni 1}}{P_{э 2}}= \\
=K_{p x 21} K_{\epsilon 12}=2.17 \cdot 0.5=1.085,
\end{gathered}
$$

Таким образом, расчеты показывают, что двухконтурная система с последовательно соединенными кондиционерами работает на 8,5\% эффективнее, чем одноконтурная.

Был выполнен расчет $\varepsilon_{\kappa}$ - коэффициента трансформации (холодильного коэффициента) как еще одного параметра, характеризующего эффективность холодильных машин с целью проверки полученных результатов:

$$
\varepsilon_{\kappa}=\frac{T_{X}}{T_{\Gamma}-T_{X}},
$$

где $T_{X}$ - абсолютная температура охлаждаемого объекта (кипения хладагента), $T_{\Gamma}$ - абсолютная температура окружающей среды (конденсации хладагента).

Нас, как и в предыдущем случае, интересует не абсолютное значение этих величин для одноконтурной и двухконтурной систем, а соотношение данных величин для этих систем. Соотношение коэффициента трансформации двухконтурной системы к одноконтурной $-K_{\varepsilon}$ будет иметь вид:

$$
\begin{gathered}
K_{\varepsilon}=\frac{\varepsilon_{2}}{\varepsilon_{1}}=\frac{\frac{T_{X 2}}{T_{\Gamma 2}-T_{X 2}}}{\frac{T_{X 1}}{T_{\Gamma 1}-T_{X 1}}}= \\
=\frac{T_{X 2} \cdot\left(T_{\Gamma 1}-T_{X 1}\right)}{\left(T_{\Gamma 2}-T_{X 2}\right) \cdot T_{X 1}},
\end{gathered}
$$


где $T_{X 1}$ и $T_{X 2}$ - абсолютная температура охлаждаемого объекта (кипения хладагента) одноконтурной и двухконтурной систем соответственно, $T_{\Gamma 1}$ и $T_{\Gamma 2}-$ абсолютная температура окружающей среды (конденсации хладагента) одноконтурной и двухконтурной систем соответственно.

Подставив в (11) значения температур, полученные экспериментально: $T_{X I}=14^{\circ} \mathrm{C} ; T_{X 2}=15^{\circ} \mathrm{C}$; $T_{\Gamma 1}=T_{\Gamma 2}=35^{\circ} \mathrm{C}$, получим значение $K_{\mathcal{E}}=1,05$.

Полученные расчеты показывают, что коэффициент трансформации у двухконтурной системы с последовательно соединенными кондиционерами на $5 \%$ выше, чем у одноконтурной, что соотносится с результатами эффективности данной системы.

Таким образом, можно сделать вывод, что система с последовательным соединением двух парокомпрессионных установок работает эффективнее, чем одноконтурная, но при этом следует отметить, что на эффективность данной системы значительное влияние имеют параметры рабочего тела.

Выводы. 1. Установлено, что основным недостатком теплового насоса является обратная зависимость его эффективности от разницы температур между источником теплоты и потребителем, а также, то что существенным недостатком парокомпрессионных ТНУ является необходимость подвода и отвода теплоты при постоянной температуре.

2. Экспериментально подтверждено, что двухконтурная система с последовательно соединенными кондиционерами работает эффективнее, чем одноконтурная.

3. Обосновано, что коэффициент трансформации двухконтурной системы с последовательным соединением парокомпрессионных установок выше, чем у одноконтурной. А значение этого параметра в существенной степени зависит от параметров рабочего тела.

4. Доказано, что уменьшение коэффициента трансформации $\varphi$ происходит не прямо пропорционально увеличению температуры подающего теплоносителя, а имеет некоторое ускорение, обусловленное повышением тепловых потерь в системе связанных с увеличением давления и температуры. При этом коэффициент ускорения увеличивается пропорционально увеличению температуры подающего теплоносителя.

1. Алимгазин А.Ш., Бахтиярова С.Г., Бергузинов А.Н. Экологические аспекты применения теплонасосных технологий для теплоснабжения различных объектов в республике Казахстан. Вестник ПГУ №1. 2010. С. 42-52.

2. Безродний М.К., Галан М.А. Енергетична ефективність теплонасосоної системи вентиляції 3 рекуператором теплоти і рециркуляцією відпрацьованого повітря. Наукові вісті НТУУ «КПІ». 2011. №2. С. 16-19.

3. Басок Б.И., Беляева Т.Г., Рутенко А.А., Лунина А.А. Анализ экономической эффективности при реализации теплонасосных систем для теплоснабжения. Пром. теплотехника. 2008. №4. С. 56-63.

4. Варгафтик Н.Б. Справочник по теплофизически свойствам вещества. М. Наука. 1972 г.

5. Гошовський C.B., Зурьян А.В. Извлечение энергии тепла Земли. LAMBERT Academic Publishing. 2018. 296 c.

6. Гошовський С.В., Зурьян А.В. Анализ применения различных источников возобновляемой энергии для оптимальной работы теплонасосных систем. Сборник научных трудов Украинского государственного геологоразведочного института. 2015. №2. С. 9-20.

7. Гошовський С.В., Зурьян А.В. Грунтовые теплообменники (ГТ) для геотермальних систем теплоснабжения оптимальне конструкции и характеристики. Сборник научных трудов Украинского государственного геологоразведочного института. 2013. №4. С. 168-184.

8. Документация для проектирования Bosch Thermotechnik 6720642483 (2009/12).

URL: https://www.bosch-

climate.ru/files/201212111351220.Condens\%207000\%20W.pdf

9. Елистратов С.Л. Комплексное исследование эффективности тепловых насосов: дисс. доктора техн. наук: 01.04.14. Новосибирск. 2010. 383 с.

10.Забулонов Ю.Л. Оцінка впливу об'єктів електроенергетики на природне середовище та стан здоров'я населення. Захист довкілля від антропоген. навантаж. Зб. наук. пр. 2005. Вип. 11(13).

11.Ильин Р.А., Ильин А.К. Новый подход к оценке эффективности тепловых насосов. Вестник АГТУ. Сер. Морская техника и технология. 2010. №2. С. 83-87.

12. Калнинь И.М. Техника низких температур на службе энергетики. Холодильное дело. 1996. №1. С. 26-29.

13. Каплун B.B. Засади сталого розвитку паливноенергетичного комплексу україни у світлі виконання вимог конвенцій РІО. Вісник КНУТД. 2014. №5 (79). С. 64-69.

14.Качинський А.Б., Хміль Т.А. Екологічна безпека України: аналіз, оцінка та державна політика. К. НІСД. 1997. $127 \mathrm{c}$.

15. Кидрук М.И. Моделирование и оптимизация систем теплоснабжения зданий с использованием возобновляемых источников энергии. Нова тема. 2007. №4. С. 13-16.

16. Корчевой Ю.П., Вольчин И.А., Горбунов В.С. та ін. Экологические аспекты развития теплоэнергетики Украины. Энергетика и электрификация. 2002. №2. С. 45-50.

17.Кудря С.О. Стан та перспективи розвитку відновлюваної енергетики в Україні. Вісник НАН України. 2015. №12. C. 19-26.

18.Лимаренко А.Н., Тараненко О.О. Экологические последствия получения и использования геотермальной энергии в Украине. Технологический аудит и резервы производства. 2015. №3/1(23).

19. Любчик Г.Н. Экологические показатели воздействия энергетических установок на окружающую среду. Промышленная теплотехника. 1992. т.14. №1-3. С. 72-78.

20. Мацевитий Ю.М., Чиркин Н.Б., Богданович Л.С., Клепанда А.С. Внедрение теплонасосных установок. Экотехнологии и ресурсосбережение. 2008. №3. С. 4-10.

21. Накорчевский А.И. Грунтовые аккумуляторы теплоты и модернизация коммунальной теплоенергетики. К. Институт технической теплофизики НАН Украины. 2010. 254 с.

22.Некрасова О.А. Синяк Ю.В. Исследование теплонасосных систем отопления (модельный подход). Теплоэнергетика. 1986. №11. С. 30-34.

23. Области применения тепловых наосов. URL: https://www.atmosfera.ua/ heatpump/oblasti-primeneniya-tn/ 
24. Овчаров С.В., Стребков А.А., Буряк А.В. Разработка комбинированной системы отопления жилых домов и коммунальных объектов в сельской местности. Технологический аудит и резервы производства. 2015. №1(21). Том 1. C. 46-51.

25. Олийниченко В.Г., Марченко Е.В. Сравнительный анализ типов технологического исполнения тепловых насосов. Возобновляемая энергетика и энергоэффективность в XXI столетии: Материалы XYIII Международной научнопрактической конференции (27-29 сент. 2017 г.). Киев. 2017. C. 604-609.

26. Петин Ю.М., Накоряков В.Е. Тепловые насосы. Российский химический журнал. 1999. Т. 41. №6. С. 107-111.

27. Попов A.B. Анализ эффективности различных типов тепловых насосов. Журнал «Проблемы энергосбережение». №1-2, август 2005 г.

URL:

http://www.energosovet.ru/stat422.html.

28.Потапова А.А., Султангузин И.А. Применение тепловых насосов в системе теплоснабжения промышленного предприятия и города. Металлург. 2010. №9. С. 44-51.

29.Прутська О.О., Федик О.Ю. Сучасний стан та проблеми розвитку альтернативної енергетики в Україні. Збірник наукових праць ВНАУ (Вінницький національний аграрний університет). 2012. №1(56). Том 2. С. 158-164.

30. Расчет холодильной машины. URL: http://twt.mpei.ac.ru/TTHB/2/T_T_5_2_1_Ref.html

31.Розен В.П., Соловей А.И., Балашев А.А. Методические указания для работы студентов по лабораторному практикуму по курсам «Модели и методы оптимизации систем электроснабжения», «Автоматизированные системы управления и переработки информации» и «Энергетический менеджмент». К. 1999. 27 с.

32. Татаринова Г.Г. Методология анализа данных в социологии. Условие транзитивности. URL:

http://society.polbu.ru/tatarova_sociology33_all.html

33. Тепловой насос. URL:

https://ru.wikipedia.org/wiki/Тепловой_насос

34. Федянин В.Я., Карпов М.К. Использование грунтовых теплообменников в системах теплоснабжения. Ползуновский вестник. №4. 2006. С. 98-103.

35. Федянин В.Я., Михеев Д.Д. Методика расчета тепловых потоков в грунтовом теплообменнике. Горизонты образования. 61-я научно-техническая конференция студентов, аспрантов и профессорско-препода-вательского состава 2003. Вып. 5. Ч. 11. С. 12-15.

36.Хайнрих Г., Найорк Х., Нестлер В.Тепловые установки для отопления и горячего водоснабжения Стройиздат. М. 1985. $351 \mathrm{c.}$

37.Шаталов И.К., Фролов М.Ю., Шаталов И.К. Схема теплонасосной установки с параллельным подключением. Вестник РУДН, сер. Инженерные исследования. 2003 №1. C. $103-105$

38. Яценко Л.В. Визначення ефективності застосування комбінованих енергосистем на основі відновлюваних джерел енергії. Технічна електродинаміка. Ч.1. Київ. 1999. C. $34-41$.

\section{ОДНОКОНТУРНІ ТА ДВОКОНТУРНІ ТЕПЛОНАСО- СНІ СИСТЕМИ. ВЗАЕМОЗВ'ЯЗОК ФІЗИЧНИХ ПРО- ЦЕСІВ ТА ЕФЕКТИВНОСТІ}

\author{
С. В. Гошовський, доктор технічних наук, проф., \\ О. В. Зур'ян, кандидат технічних наук
}

Український державний геологорозвідувальний інститут 04114 вул. Автозаводська, 78А, Київ

Наведено теоретичний аналіз особливостей використання $i$ технологій побудови одноконтурних та двоконтурних теп- лонасосних систем. Виконано аналіз основних недоліків одноконтурних теплонасосних систем. Аналітично обтрунтовано, що проиес теплообміну відбувається при змінних температурах з боку джерела і приймача теплоти, щуо веде до додаткових втрат в випарнику $i$ конденсаторі $\check{u}$, відповідно, до зниження коефіиієнта трансформачії теплонасосної системи. Експериментально встановлено, що зменшення коефічієнта трансформачії відбувається не прямо пропориійно збільшенню температури теплоносія на вході в систему, а має деяке прискорення, обумовлене підвищенням теплових втрат в системі, пов'язаних із збільшенням тиску $і$ температури. Представлено діючий макет розробленої і сконструйованої в УкрДГРІ двоконтурної експериментальної теплонасосної системи. Описана методика проведення досліджень. Наведено характеристи$\kappa и$ вимірювального обладнання, щзо було встановлено на макеті експериментальної установки й програмного забезпечення, яке використовувалося для архівування і візуалізації даних, отриманих в прочесі проведення досліджень. Викладені результати наукової роботи, отримані в ході теоретичних розрахунків і експериментальних досліджень ефективності теплонасосних систем, в залежності від одноконтурного або двоконтурного виконання. Даються залежності коефічієнта трансформачії теплового насоса від кількості контурів. Обтрунтовано залежність ефективності теплонасосної системи від параметрів первинного джерела низькопотениійного тепла і конструктивних особливостей системи теплопостачання. Зроблено висновок, щуо двоконтурна система з послідовно з'єднаними контурами працює ефективніше, ніж одноконтурна. Бібл. 38, табл. 1, puc. 6.

Ключові слова: тепловий насос, двоконтурний тепловий насос, енергія довкілля, відновлювані джерела енергії.

\section{REFERENCES}

1. Alimgazin A.Sh., Bahtiyarova S.G., Berguzinov A.N. Ekolohichni aspekty zastosuvannya teplonasosnykh tekhnolohiy dlya teplopostachannya riznykh obyektiv $\mathrm{v}$ respublitsi Kazakhstan. [Environmental aspects of the application of heat pump technologies for heat supply of various objects in the Republic of Kazakhstan]. Vestnik PGU No. 1. 2010. Pp. 42-52. [in Russian]

2. Bezrodnyj M.K. Galan M.A. Enerhetychna efektyvnist teplonasosovoyi systemy ventylyatsiyi z rekuperatorom teploty $\mathrm{i}$ retsyrkulyatsiyeyu vidpratsovanoho povitrya. [Energy efficiency of the heat pump pump system for ventilation with heat recovery and recirculation of exhaust air]. Naukovi visti NTUU «KPI». 2011. No. 2. Pp. 16-19. [in Ukrainian]

3. Basok B.I., Belyaeva T.G., Rutenko A.A., Lunina A.A. Analiz ekonomichnoyi efektyvnosti pry realizatsiyi teplonasosnykh system dlya teplonavantazhennya. [Analysis of economic efficiency in the implementation of heat pump systems for heat supply]. Prom. teplotehnika. 2008. No. 4. Pp. 56-63. [in Russian].

4. Vargaftik N.B. Spravochnyk po teplofyzycheskym svoystvam rechovyn. [Handbook of thermophysical properties of substances]. M. Nauka. 1972. [in Russian].

5. Goshovskiy S.V., Zurian A.V. Izvlecheniye energii tepla Zemli. [Extraction of energy of heat of the Earth]. LAMBERT Academic Publishing. 2018. 296p. [in Russian].

6. Goshovskiy S.V., Zurian A.V. Analiz primeneniya razlichnykh istochnikov vozobnovlyayemoy energii dlya opmal'noy raboty teplonasosnykh sistem. [Analysis of the application of various renewable energy sources for optimal operation of heat pump systems]. Sbornik nauchnyih trudov Ukrainskogo gosudarstvennogo geologorazvedochnogo instituta. 2015. No. 2. Pp. 9-20. [in Russian] 
7. Goshovskiy S.V., Zurian A.V. Gruntovyye teploobmenniki (GT) dlya geotermal'nykh sistem teplosnabzheniya optimal'noye konstruktsii i kharakteristiki. [Soil heat exchangers (GT) for geothermal heating systems are optimally designed and features]. Sbornik nauchnyih trudov Ukrainskogo gosudarstvennogo geologorazvedochnogo institute. 2013. No. 4. Pp. 16-184. [in Russian].

8. Dokumentatsiya dlya proyektirovaniya Bosch Thermotechnik 6720642483 (2009/12). [Design documentation Bosch Thermotechnik 6720642 483(2009/12)]. Retrived from https://www.boschclimate.ru/files/201212111351220.Condens $\% 207000 \% 20 \mathrm{~W}$.pdf [in Russian].

9.Elistratov S.L. Kompleksnoye issledovaniye ef-fektivnosti teplovykh nasosov [Comprehensive study of the effectiveness of heat pumps]. diss. doktora tehn. nauk: 01.04.14. Elistratov Sergey Lvovich. .Novosibirsk. 2010. 383 p. [in Russian].

10. Zabulonov Yu.L. Otsinka vplivu obyektiv elektronerhetiki na pryrodno seredovyshche ta stan zdorovya naselenyynya. Zakhyst dovkillya vid antropohen. navantazh. [Estimation of influence of objects of electric power industry on the natural environment and state of health of the population Zaxyst dovkillya vid antropogen. navantazh]. Zb. nauk. pr. 2005. No. 11(13). Pp. 58-64. [in Ukrainian].

11. Ilin R.A., Ilin A.K. Novyy podkhod $\mathrm{k}$ otsenke effektivnosti teplovykh nasosov. [New approach to evaluating the efficiency of heat pumps]. Vestnik AGTU. Ser.: Morskaya tehnika i tehnologiya. 2010. №2. Pp. 83-87. [in Russian]

12. Kalnin I.M. Tekhnika nizkikh temperatur na sluzhbe energetiki. [Technique of low temperatures in the service of energy]. Holodilnoe delo. 1996. No. 1. Pp. 26-29. [in Russian].

13. Kaplun V.V. Zasady staloho rozvytku palyvnoenerhetychnoho kompleksu ukrayiny u Svitli Vykonannya vymoh konventsiy RIO. [Principles of sustainable development of Ukraine's fuel and energy complex in the light of the requirements of the RIO conventions]. Visnyk KNUTD. 2014. No. 5(79). Pp. 64-69. [in Ukrainian].

14. Kachynskyj A.B., Xmil T.A. Ekolohichna bezpeka Ukrayiny: analiz, otsinka ta derzhavna polityka. [Ecologica safety of Ukraine: analysis, evaluation and state policy]. K NISD. 1997. 127 p. [in Ukrainian].

15. Kidruk M.I. Modelirovaniye i optimizatsiya sistem teplosnabzheniya zdaniy s vnedreniyem vozobnovlyayemykh istochnikov energii. [Modeling and optimization of building heat supply systems using renewable energy sources]. Nova tema. 2007. No. 4. Pp. 13-16. [in Russian].

16. Korcheviy YU.P., Volchin I.A., Horbunov V.S. ta in. Ekolohichni aspekty rozvytku teploenerhetyky Ukrayiny. [Environmental aspects of the development of heat and power engineering of Ukraine]. Energetika i elektrifikatsii. 2002. No. 2. Pp. 45-50. [in Ukrainian].

17. Kudrya S.O. Stan ta perspektyvy rozvytku vidnovlyuvanoyi enerhetyky v Ukrayini. [Status and Prospects for the Development of Renewable Energy in Ukraine]. Visnik NAN Ukraïni. 2015. No. 12. Pp. 19-26. [in Ukrainian].

18. Limarenko A.N., Taranenko O.O. Ekologicheskiye posledstviya polucheniya $\mathrm{i}$ ispol'zovaniya geotermal'noy energii $v$ Ukraine. [Ecological consequences of obtaining and using geothermal energy in Ukraine]. Tehnologicheskiy audit i rezervy proizvodstva. 2015. No.3/1(23). Pp. 19-26. [in Russian].

19. Lyubchik G.N. Ekologicheskiye pokazateli vozdeystviya energeticheskikh ustanovok na okruzhayushchuyu sredu. Promyshennaya teplotekhnika. [Environmental indicators of the impact of energy installations on the environment]. Promyshlennaya teplotehnika. 1992. T.14. No.1-3. Pp. 72-78. [in Russian].

20. Macevitiy Yu.M., Chirkin N.B., Bogdanovich L.S., Klepanda A.S. Vnedreniye teplonasosnykh ustanovok.
Ekotekhnologii i resursosberezheniye. [Introduction of heat pump installations]. Ekotehnologii i resursosberezhenie. 2008. No.3. Pp. 4-10. [in Russian]

21. Nakorchevskiy A.I. Gruntovyye akkumulyatory teploty i modernizatsiya kommunal'noy teploenergetiki. [Soil accumulators of heat and modernization of municipal heat and power engineering]. K. Institut tehnicheskoy teplofiziki NAN Ukrainy. 2010. 254 p. [in Russian].

22. Nekrasova O.A., Sinyak Yu.V. Issledovaniye teplonasosnykh sistem otopleniya (modelnyy podkhod). [Research of heat pump systems of heating (model approach)]. Teploenergetika. 1986. No.11. Pp. 30-34. [in Russian].

23. Oblasti primeneniya teplovykh naosov. [Application areas of thermal pumps]. Retrived from: https://www.atmosfera.ua/heatpump/oblasti-primeneniya-tn/ 1. [in Russian].

24. Ovcharov S.V., Strebkov A.A., Buryak A.V. Razrabotka kombinirovannoy sistemy otopleniya zhilykh domov i kommunal'nykh ob"yektov v sel'skoy mestnosti. [Development of a combined heating system for residential and public buildings in rural areas]. Tehnologicheskiy audit i rezervy proizvodstva. 2015. No.1(21). T. 1. Pp. 46-51. [in Russian]

25. Oliynichenko V.G., Marchenko E.V. Sravnitelnyy analiz tipov tekhnologicheskogo ispolneniya teplovykh nasosov. [Comparative analysis of the types of technological performance of heat pumps]. Vozobnovlyaemaya energetika i energoeffektivnost $\mathrm{v}$ XXI stoletii: Materialy XYIII Mezhdunarodnoy nauchno prakticheskoy konferencii. Kiev. 2017. Pp. 604-609. [in Russian].

26. Petin Yu.M., Nakoryakov V.E. Teplovyye nasosy. [Heat pumps]. Rossiyskiy himicheskiy zhurnal. 1999. T. 41. No. 6. Pp. 107-111. [in Russian].

27. Popov A.V. Analiz effektivnosti razlichnykh tipov teplovykh nasosov. [Analysis of the effectiveness of various types of heat pumps]. Zhurnal «Problemy energosberezhenie». 2005. No.1-2. Retrived from:

http://www.energosovet.ru/stat422.html [in Russian]

28. Potapova A.A., Sultanguzin I.A. Primeneniye teplovykh nasosov v sisteme teplosnabzheniya promyshlennogo predpriyatiya i goroda. [The use of heat pumps in the heat supply system of industrial enterprises and the city]. Metallurg. 2010. No.9. Pp. 44-51. [in Russian].

29. Prutska O.O., Fedyk O.Yu. Suchasnyy stan ta problemy rozvytku al'ternativnoyi enerhetyky v Ukrayini. [Current state and problems of alternative energy development in Ukraine]. Zbirnyk naukovykh prats VNAU (Vinnytskyy natsionalnyy ahrarnyy universytet). 2012. No.1(56). T. 2. Pp. 158-164. [in Ukrainian].

30. Raschet kholodil'noy mashiny. [Calculation of the refrigeration machine]. Retrived from: http://twt.mpei.ac.ru/TTHB/2/T_T_5_2_1_Ref.html [in Russian]

31. Rozen V.P., Solovey A.I., Balashev A.A. Metodicheskiye ukazaniya dlya raboty studentov po laboratornomu praktikuma po kursam «Modeli i metody optimizatsii sistem elektrosnabzheniya», «Avtomatizirovannyye sistemy upravleniya i pererabotki informatsii» $\mathrm{i}$ «Energeticheskiy menedzhment». [Guidelines for the work of students in laboratory practical work on the courses "Models and methods for optimizing power supply systems", "Avtomatizirovannye sistemy upravleniya i pererabotki informacii» $\mathrm{i}$ «Energeticheskiy menedzhment»]. K. 1999. 27 p. [in Russian].

32. Tatarinova G.G. Metodologiya analiza dannykh v sotsiologii. Usloviye tranzitivnosti. [Methodology of data analysis in sociology. Transitivity condition]. Retrived from: http://society.polbu.ru/tatarova_sociology33_all.html [in Russian].

33. Teplovoy nasos. [Heat pump]. Retrived from: https://ru.wikipedia.org/wiki/Тепловой_насос [in Russian]

34. Fedyanin V.Ya., Karpov M.K. Ispolzovaniye gruntovykh teploobmennikov $\mathrm{v}$ sistemakh teplosnabzheniya. 
[The use of ground heat exchangers in heating systems]. Polzunovskiy vestnik. №4. 2006. Pp. 98-103. [in Russian].

35. Fedyanin V.Ya., Miheev D.D. Metodika rascheta teplovykh potokov $\mathrm{v}$ gruntovykh teploobmennike. [The method of calculating the heat flow in the soil heat exchanger]. Gorizonty obrazovaniya. 61-ya nauchno-tehnicheskaya konferenciya studentov, asprantov i professorsko-prepodavatelskogo sostava. 2003. No. 5. T. 11. Pp. 12-15. [in Russian].

36. Haynrih G., Nayork H., Nestler V. Teplovyye ustanovki dlya otopleniya i goryachego vodosnabzheniya. [Thermal installation for heating and hot water]. Stroyizdat. M.
1985. 351 p. [in Russian].

37. Shatalov I.K., Frolov M.Yu. Skhema teplonasosnoy ustanovki s parallel'nym podklyucheniyem. [Scheme of heat pump installation with parallel connection]. Vestnik RUDN, ser. Inzhenernye issledovaniya. 2003. No.1. Pp. 103-105. [in Russian].

38. Yacenko L.V. Opredeleniye effektivnosti primeneniya kombinirovannykh energosistem na osnove vozobnovlyayemykh istochnikov energii. [Determination of efficiency of application of combined power systems on the basis of renewable energy sources]. Texnichna elektrodynamika. 1999. T.1. Pp. 34-41. [in Russian].

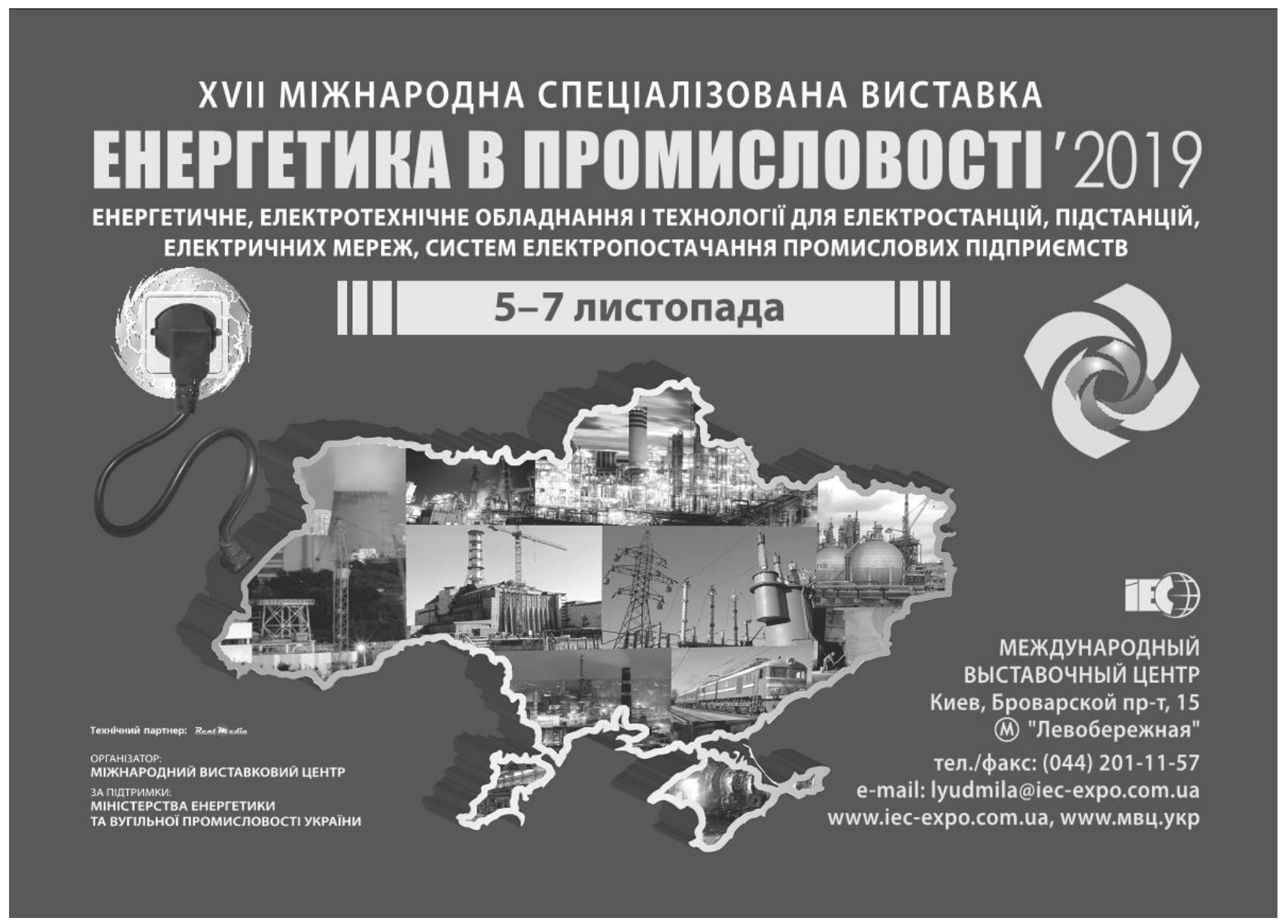

